\title{
REPORT ON THE WROCLAW SEMINAR IN CRIMINAL Procedure "The CONCEPT, POSITION AND Significance of Truth in Criminal Procedure" (WROCLAW, 11 MARCH 2013)
}

\author{
KAROLINA KREMENS*
}

The University of Wrocław Faculty of Law, Administration and Economics hosted a seminar organized by the Department of Criminal Procedure held on 11 March 2013. The conference marked the beginning of the Wrocław Seminars in Criminal Procedure series. The meetings are intended to be held every year in mid-March in Wrocław, establishing a place for debate and discussion on the most important issues related to criminal procedure.

This year's edition of the Wrocław Seminar in Criminal Procedure was devoted to the truth - its concept, position and significance in criminal procedure. It also alluded to upcoming changes in the Polish Code of Criminal Procedure. The intention of the Seminar's organizers was to address issues relating to theoretical and dogmatic aspects of the law of criminal procedure. As Professor Jerzy Skorupka, the Chair of the Department of Criminal Procedure and Chairman of the Seminar's Scientific Committee, emphasized during his opening speech, it is all the better if the theme of a seminar in a given year refers to current issues; in this case, questions associated with changes in the Code of Criminal Procedure. And so it was this year.

The Seminar was officially opened by Professor Włodzimierz Gromski, Dean of the Faculty of Law, Administration and Economics, who welcomed the guest speakers and participants. He expressed his joy associated with the inauguration of the new initiative, especially since the meeting took a place in the form of seminar providing an atmosphere that facilitated the free exchange of views in an open environment.

The first panel was led by Professor Ryszard Stefański from the Łazarski School in Warsaw. The first paper was presented by Professor Jerzy Zajadło from the University of Gdańsk. Professor Zajadło presented his views on the theoretical and philosophical concept of the truth in

DOI: $10.2478 /$ wrlae-2014-0105

* Phd, LL.M., Department of Criminal Procedure University of Wrocław Faculty of Law, Administration and Economics. 
criminal procedure. He pointed out that Anglo-Saxon communities are beginning to perceive a lack of truth in their criminal trials, while lawyers working in the continental legal culture are starting to feel an excess of it. The speaker posed three questions to be answered during the lecture: 1) where does the deficit of truth in the philosophy derive from? 2) what is the source of natural fertility in describing the truth in philosophy? 3) which of these results may be useful in jurisprudence, particularly in the criminal process? In conclusion, Professor Zajadło stated that the truth should always be the objective of criminal proceedings.

The second lecture was presented by Professor Paweł Wiliński from Adam Mickiewicz University in Poznan. His lecture was related to the constitutional basis of the principle of material truth. Professor Wiliński began by saying that the truth is means to materializing justice, but at the same time, unfortunately, lawyers focus rather on truth than on justice. In his presentation the speaker set his objective as establishing whether the principle of material truth can be derived from the Polish Constitution, considering that it is not explicitly posited in it. Professor Wiliński, speaking from the position of an expert in criminal procedure on one hand and a Constitutional lawyer on the other, concluded that the right to trial expressed in Article 45(1) and (2) of the Constitution is not an independent basis for the principle of material truth. That principle, in his opinion, can be derived from taking Articles 45 and Articles 1, 2, 7 of the Constitution together with its Preamble.

The next speaker, Professor Stanisław Waltoś from the Jagiellonian University, addressed the function that principle of material truth plays in the current model of Polish criminal process. He began by saying that the Polish criminal process strives to achieve a perfection in which all judgments are made according to the truth, without realizing that this cannot be accomplished. Professor Waltoś presented a historical overview of ways of striving to achieve the truth in a criminal trial, as well as the evolution of the principle of material truth in Polish criminal procedure. He highlighted the pressure which the Polish Code of Criminal Procedure puts on the activity of the court, which makes it directly responsible for ascertaining the truth. In his conclusion Professor Waltoś criticized the system in which most criminal cases have no social component in making the final decision (e.g. a jury), and can therefore lead to the feeling of an absence of internal reflection by the judge who rules as an individual.

The last speaker during this part of the Seminar was Professor Piotr Hofmański, also from the Jagiellonian University. His lecture focused on the principle of truth in the proposed model for Polish criminal process. He reiterated the statement made by him in the past that changes in the model of criminal proceedings will bring us closer to the truth rather than further from it during trials. In his view, the new Code of Criminal Procedure will simply necessitate a new approach by the parties to a criminal trial, and through their activity the truth will be revealed. Professor Hofmański also expressed his disapproval of the adoption of a rule that allows the court to act exceptionally proprio motu (on its own initiative) when admitting evidence during a trial. At the conclusion of his lecture, Professor Hofmański stressed that under the new Code the truth will be established 
during criminal proceedings, but it will be a truth understood slightly differently than before.

In the discussion initiated by Professor Stefański, opinions on the issue of the truth in criminal process were delivered by Professor Kazimierz Zgryzek, Professor Piotr Kardas, Dr Łukasz Chojniak, Dr Eliana Trybuchowska and Dr Wojciech Jasiński.

The second panel, chaired by Professor Kazimierz Zgryzek from the University of Silesia, opened with a presentation by Dr Wojciech Jasiński from the University of Wroclaw, who presented lecture on the model of criminal process in the light of its approach to establishing the truth. $\mathrm{He}$ presented the inquisitorial and adversarial models of criminal process as well as their advantages and disadvantages. Dr Jasiński concluded that the choice of model depends on the existing relationship between the individual and the state, and its axiological framework. The final lecture was given by Professor Sławomir Steinborn from the University of Gdańsk, who spoke about axiological considerations in limiting the drive to establish the truth in a criminal trial. In his speech, Professor Steinborn discussed the conditions under which the truth can be restricted. He also touched upon the issue of admissibility of illegally obtained evidence and evidence derived from it, i.e. the fruit of the poisonous tree doctrine.

In the discussion opened after the second panel by Professor Zgryzek, opinions on the issue under discussion were delivered by participants including Professor Jerzy Skorupka, Professor Piotr Hofmański and Dr Karolina Kremens.

The Wrocław Seminar in Criminal Procedure attracted the attention of both academia and practitioners. The Departments of Criminal Law and Procedure from major Polish universities were widely represented. The Seminar was also attended by judges and prosecutors as well as the members of the Bar. Numerous graduate and undergraduate students of the University of Wrocław Faculty of Law, Administration and Economics also took part in the Seminar. It was a unique opportunity to enhance their knowledge on the fundamental principle of criminal process, i.e. the necessity to establish the truth.

In closing the Wroclaw Seminar in Criminal Procedure, Professor Jerzy Skorupka, thanking speakers and other participants, expressed his hope that the next Seminar to be held in 2014 will be as successful as this one. He also announced the publication of the lectures delivered during the Seminar, enriched with the voices heard during the discussion and articles referring to the concept, position and significance of the truth in criminal procedure. 